\title{
THE UNNAMED ATLANTIC TROPICAL STORMS OF 1970
}

\author{
DAVID B. SPIEGLER \\ Allied Research Associates, Inc., Concord, Mass.
}

\begin{abstract}
A detailed analysis of conventional and aircraft reconnaissance data and satellite pietures for two unnamed Atlantic Ocean cyclones during 1970 indicates that the storms were of tropical nature and were probably of at least minimal hurricane intensity for part of their life history.

Prior to becoming a hurricane, one of the storms exhibited characteristics not typical of any of the recognized classical cyclone types [i.e., tropical, extratropical, and subtropical (Kona)]. The implications of this are discussed and the concept of semitropical cyclones as a separate cyclone category is advanced.
\end{abstract}

\section{INTRODUCTION}

During the 1970 tropical cyclone season, two storms occurred that were not given names at the time. The National Hurricane Center (NHC) monitored their progress and issued bulletins throughout their life history but they were not officially recognized as tropical cyclones of tropical storm or hurricane intensity. In their annual postseason summary of the hurricane season, NHC discusses these storms in some detail (Simpson and Pelissier 1971) but they are not presently included in the official list of 1970 tropical storms.

The primary purpose of this paper is to present evidence that the two cyclones were indeed tropical storms, very probably of hurricane intensity and, therefore, should be included in the official list of 1970 tropical cyclones in the Atlantic Ocean.

Secondary aims are (1) to show that one of the cyclones (in its earlier history) apparently did not fit any of the present cyclone models and (2) to promote the concept of, and the need to recognize, a new separate category of cyclones - the semitropical cyclone.

The concept of an intermediate category of cyclones between those that are clearly tropical and those that are extratropical is not completely new, although at the present time it is not widely accepted. References to hybrid-type storms were made in the past by Dunn and Staff (1964), Erickson (1967), and most recently by Simpson and Pelissier (1971) who refer to the two storms discussed in this paper as "neuter cyclones" and state ". . . the need [exists] for recognizing and identifying certain hybrid storm types." The original version of this paper suggested that there is now a need to recognize the semitropical cyclone as a separate cyclone category. ${ }^{1}$ The fact that Simpson and Pelissier have independently reached the same general conclusion as the author regard-

\footnotetext{
1 The author prefers the nomenclature semitropical cyclone (rather than neuter cyclone) because he believes it is more consistent with presently recognized cyclone categories that have the word "tropical" by itself or modified by the prefixes "extra" and "sub." Thus, it appears logical to describe a cyclone that draws nearly equally on both tropical and baroclinic energy sources as "semitropical" (which literally translated means, balf tropical).
}

ing recognition of hybrid-type storms provides additional support for the recommendation.

\section{UNNAMED STORM NO. 1-AUG. 13-18, 1970}

A well-organized tropical disturbance noted on satellite pictures during August 8, south of the Cape Verde Islands in the far eastern tropical Atlantic, intensified to a strong depression as it moved westward. On Thursday, August 13, some further intensification of the system appeared to be taking place while the depression was about $250 \mathrm{mi}$ (217n.mi.) east of San Juan, Puerto Rico. Aircraft reconnaissance reported a large area of dangerous squalls and sustained wind speeds of $52 \mathrm{kt}$ for short periods with gusts above hurricane force north of the apparent center. However, the circulation characteristics typical of tropical storms were not present at the time-only very light winds were reported to the south of the center-therefore, the San Juan National Weather Service Office characterized the disturbance as an "intense tropical depression." Although there was some evidence depicted in an Applications Technology Satellite (ATS 3) film loop of the disturbance becoming better organized for a brief time on August 14, it did not acquire tropical storm characteristics. The large area of very heavy squalls with wind speeds in excess of $52 \mathrm{kt}$ for brief periods continued to be reported by reconnaissance aircraft and ships.

The system weakened during the next 2 days to a tropical wave while moving toward the southeast coast of the United States. On Monday, August 17, however, a low pressure area re-formed on the tropical wave. The newly formed tropical depression intensified throughout the day, reaching tropical storm intensity during the evening hours, and was probably of hurricane intensity during the morning hours of August 18 before encountering a cold front well off the northeast coast of the United States on the afternoon of the 18th.

Evidence of the intensification was given by coastal and ship reports, satellite pictures, and the weather radar at Cape Hatteras. (Reconnaissance by aircraft was not scheduled for late on August 17 or early on the 18th.) 
Table 1.-Cape Hatteras, N.C., radar observations of a tropical storm on Aug. 17, 1970

\begin{tabular}{|c|c|c|c|c|c|}
\hline Time & Latitude & Longitude & \multicolumn{2}{|c|}{ Diameter } & Remarks \\
\hline (GMT) & $\left({ }^{\circ} \mathbf{N}\right)$ & $\left({ }^{\circ} \mathrm{W}\right)$ & (mi) & (n. mi.) & \\
\hline 1130 & 34.8 & 76.9 & - & - & $15^{\circ}$ spiral overlay \\
\hline 1330 & 35.2 & 76.3 & 10 & (8.7) & $\begin{array}{l}\text { New center formed last hour, now } \\
\text { almost closed eye, spiral band area }\end{array}$ \\
\hline 1430 & 35. 33 & 76.3 & 12 & $(10.4)$ & $\begin{array}{l}\text { Low center closed, good fix, spiral } \\
\text { band area }\end{array}$ \\
\hline 1530 & 35.6 & 75.9 & 12 & $(10,4)$ & Do. \\
\hline 1630 & 35.67 & 75.67 & 14 & $(12.2)$ & Do. \\
\hline 1730 & 35.77 & 75.25 & 12 & $(10.4)$ & $\begin{array}{l}\text { Low center open to } \mathrm{NW} \text {, spiral band } \\
\text { area }\end{array}$ \\
\hline 1830 & 35.9 & 75.17 & 16 & (13.9) & Low center, spiral band area \\
\hline 1930 & 36.2 & 74.53 & 8 & $(6.9)$ & Closed low center, spiral band area \\
\hline 2030 & 36.4 & 74.1 & 6 & (5. 2) & Do. \\
\hline
\end{tabular}

In a 0600 EsT tropical depression bulletin on August 17, the Washington D.C. National Weather Service Office indicated that winds were about " $35 \mathrm{mph}[30 \mathrm{kt}]$ and locally stronger in a few squalls within 135 miles [117 n.mi.] of the center." As the strong tropical depression headed northward along the eastern North Carolina coast, it caused heavy rains and wind gusts above hurricane force in thunder squalls. Sustained winds at land stations were just below gale force; for example, Cape Hatteras reported sustained winds of $28 \mathrm{kt}$, gusts to $42 \mathrm{kt}$ at about $1500 \mathrm{GMT}$ (1000 EST) while the depression was about 30 n.mi. west of the station. However, as the center passed off the coast just south of Oregon Inlet during the early afternoon, Oregon Inlet reported 48-kt northwest winds at $1800 \mathrm{GMT}$ (1300 EST) and a pressure of $1011 \mathrm{mb}$ (29.85 in.). The storm was very compact, as evidenced by Cape Hatteras radar reports, indicating an eye with diameter ranging from 5 to $12 \mathrm{n}$.mi. Table 1 gives some of the information contained in the Hatteras radar reports transmitted on the Radar Report and Warning Coordination Circuit (RAWARC). Spiral rainbands typical of organized tropical storms appeared throughout the sequence of reports.

Because the storm was so compact and because aircraft reconnaissance was not scheduled, accurate information on the temperature in the storm center at low and midtropospheric levels was not available. Nevertheless, one can determine from the reported $500-\mathrm{mb}$ temperatures at Cape Hatteras that the temperature there at 1200 GMT on August 17 increased by $\approx 3^{\circ} \mathrm{C}$ in $12 \mathrm{hr}$ (from $-10^{\circ}$ to $-7^{\circ} \mathrm{C}$ ) as the depression was approaching. At that time, the center of the depression was approximately $69 \mathrm{n}$. mi. southwest of the station. One can infer from the warming at Hatteras as the depression approached that the system was very likely not cold core. [The $-7^{\circ} \mathrm{C} 500-\mathrm{mb}$ temperature represents a temperature that is slightly higher than the mean tropical atmosphere for the West Indies (Jordan $1957 a$ ) and temperatures of other mid-and low-tropospheric levels outside the vicinity of the Low center were near or slightly above that of the mean tropical atmosphere.]

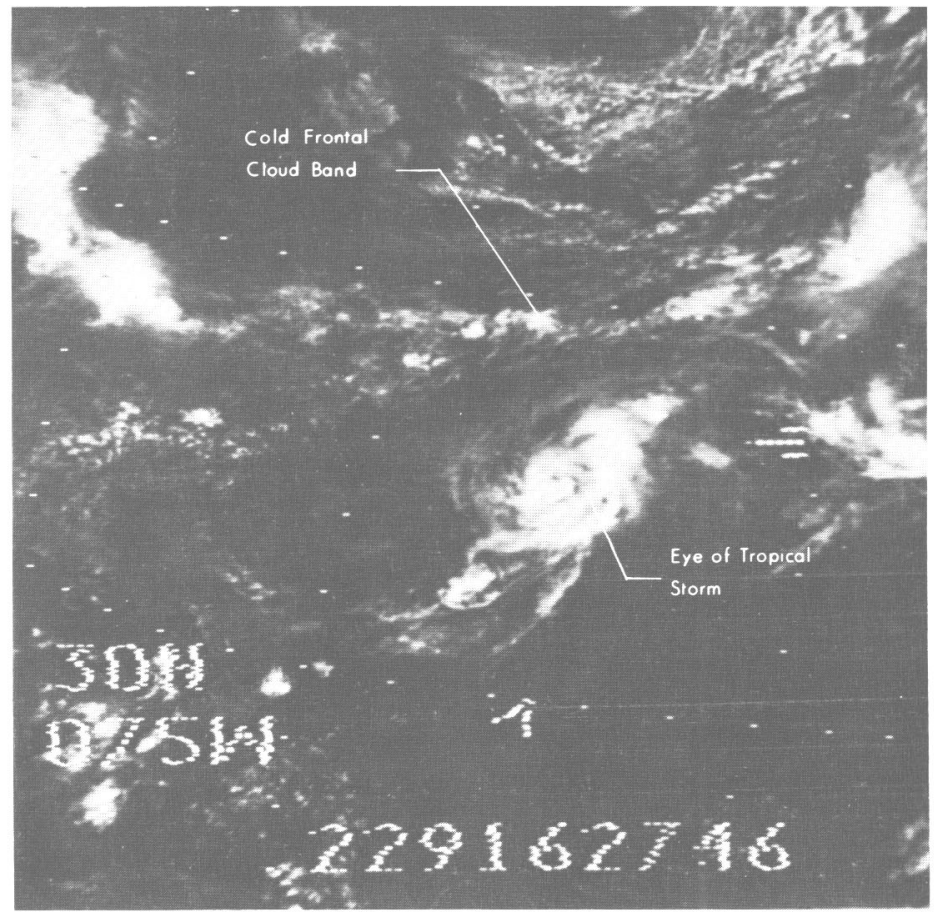

FIgURE 1.-Nimbus 3 satellite picture of a tropical storm near Cape Hatteras, N.C., at 1627 GMT, Aug. 17, 1970.

TABLE 2.-Weather observations for USCG cutter Gresham [weather ship Hotel $\left(88.0^{\circ} \mathrm{N}, 71.0^{\circ} \mathrm{W}\right)$ ] on Aug. 18,1970

\begin{tabular}{|c|c|c|c|c|c|}
\hline Time & $\mathbf{s k y}$ & Weather & $\begin{array}{l}\text { Pres- } \\
\text { sure }\end{array}$ & $\begin{array}{l}\text { Wind } \\
\text { direc- } \\
\text { tion and } \\
\text { speed }\end{array}$ & Remarks \\
\hline (GMT) & & & $(\mathrm{mb})$ & (deg./kt.) & \\
\hline 0000 & Overcast & $\dot{\nabla}]$ & 1013.6 & $220 / 11$ & \\
\hline 0100 & Overcast & $\dot{\nabla}$ & 1011.5 & $180 / 17$ & \\
\hline 0200 & Overeast & 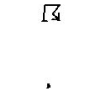 & 1009.8 & $180 / 25$ & $\begin{array}{l}\text { Heavy thundershower } 0105 \text { to } \\
0115 \text {, moderate thundershower } \\
0115 \text { to } 0150\end{array}$ \\
\hline 0300 & Overcast & $\dot{\nabla}$ & 1002.5 & $010 / 10$ & $\begin{array}{l}\text { Wind in past hour } 65 \mathrm{kt} \text { from } \\
180^{\circ} \text {, pressure falling rapidaly }\end{array}$ \\
\hline 0310 & Overcast & $\dot{\nabla}$ & 1001.0 & & \\
\hline 0400 & Overcast & $\dot{\nabla}$ & 1008.5 & $290 / 33$ & \\
\hline 0500 & Overcast & $\dot{p}]$ & 1011.1 & $270 / 38$ & \\
\hline 0600 & $\begin{array}{r}\text { Breaks in } \\
\text { overcast }\end{array}$ & $\dot{\nabla}]$ & 1012.8 & $270 / 34$ & \\
\hline 0700 & $\begin{array}{l}\text { Partly } \\
\text { cloudy }\end{array}$ & $\longrightarrow$ & 1013.2 & $290 / 30$ & \\
\hline
\end{tabular}

$\dot{p}]$ shower ended in past hour

$\dot{\nabla}$ shower

IZ heavy thundershower

, drizzle

Satellite pictures taken at midday on August 17 confirmed the well-organized cloud pattern and showed that the storm had developed an eye (fig. 1). A cold frontal cloud band is noted several hundred miles to the north of the tropical storm. An ATS 3 film loop also indicated progressively better organization of the system throughout the day. 


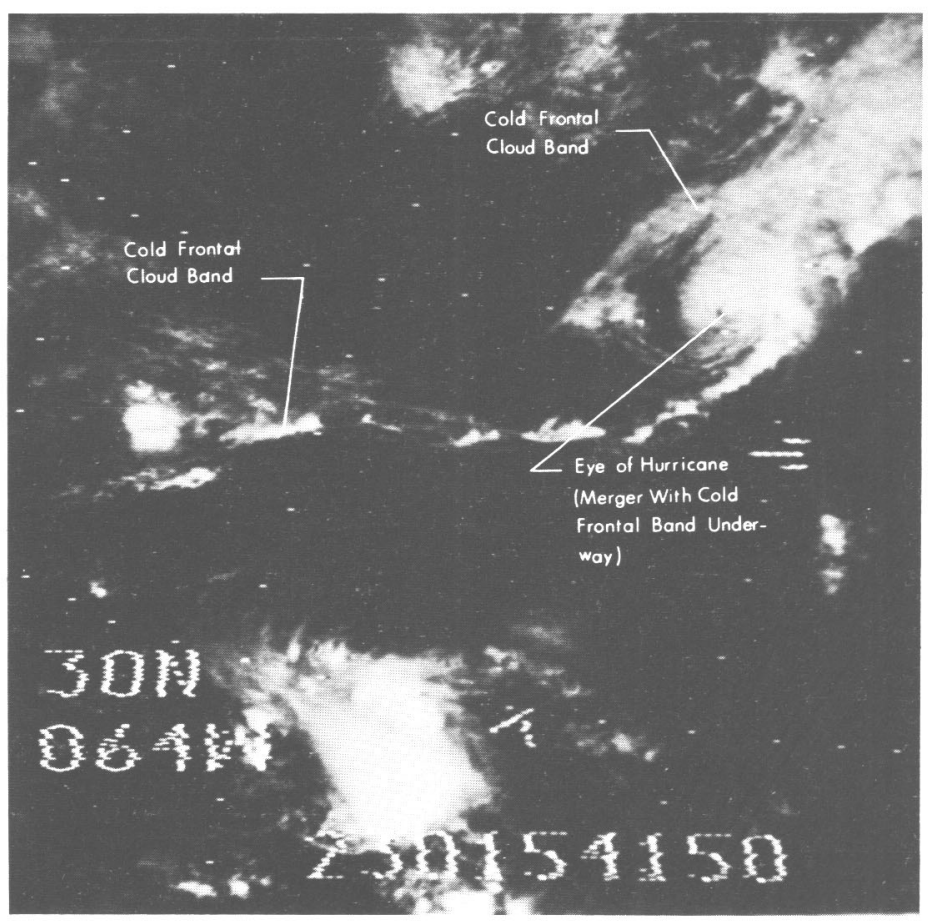

Figure 2.-Nimbus 3 satellite picture of hurricane near $41.5^{\circ} \mathrm{N}$, $61.6^{\circ} \mathrm{W}$, at $1542 \mathrm{GMT}$, Aug. 18, 1970.

The next indication of continued storm intensification came from reports transmitted by wéather ship Hotel [U.S. Coast Guard (USCG) cutter Gresham] located at $38^{\circ} \mathrm{N}$, $71^{\circ} \mathrm{W}$. Sea-level pressure which had been falling slowly from mid-day to dark began to fall rapidly. Excerpts from the ship's $\log$ (table 2) for the period 0000 to 0600 GMT on August 18 (1900 EST, August 17 to 0100 EST, August 18) show pressure falling very rapidly, $7.3 \mathrm{mb}$ between 0200 and $0300 \mathrm{GMT}$ to $1002.5 \mathrm{mb}$ (29.60 in.) and a further fall to a minimum of $1001 \mathrm{mb}(29.56 \mathrm{in}$.) at $0310 \mathrm{GMT}$-indicating a deepening of $\approx 10 \mathrm{mb}$ in the $9-\mathrm{hr}$ period between 1800 GMT on August 17 when the storm was passing near Oregon Inlet and the time it arrived at ship Hotel at $0300 \mathrm{GMT}$ on August 18. At the same time, winds increased to a maximum of $65 \mathrm{kt}(74 \mathrm{mi} / \mathrm{hr}$; i.e., hurricane force) from a southerly direction before the minimum pressure was reached. Showers and heavy thundershowers were reported throughout the $6-\mathrm{hr}$ period ending at $0600 \mathrm{GmT}$.

The data discussed above provides compelling evidence in favor of the conclusion that the tropical depression intensified to near hurricane strength with gale- to hurricane-force winds concentrated in a very small area near the center. The forward speed of the storm from the time it passed off the North Carolina coast to the time it arrived at ship Hotel is computed to be $\approx 30 \mathrm{kt}$. Because the storm deepened about $10 \mathrm{mb}$ during this 9 -hr period, we can assume an average deepening rate of slightly more than $1 \mathrm{mb} / \mathrm{hr}$. The pressure fall of $7.3 \mathrm{mb}$ in $1 \mathrm{hr}$ reported at Hotel was then due largely to the forward motion of the

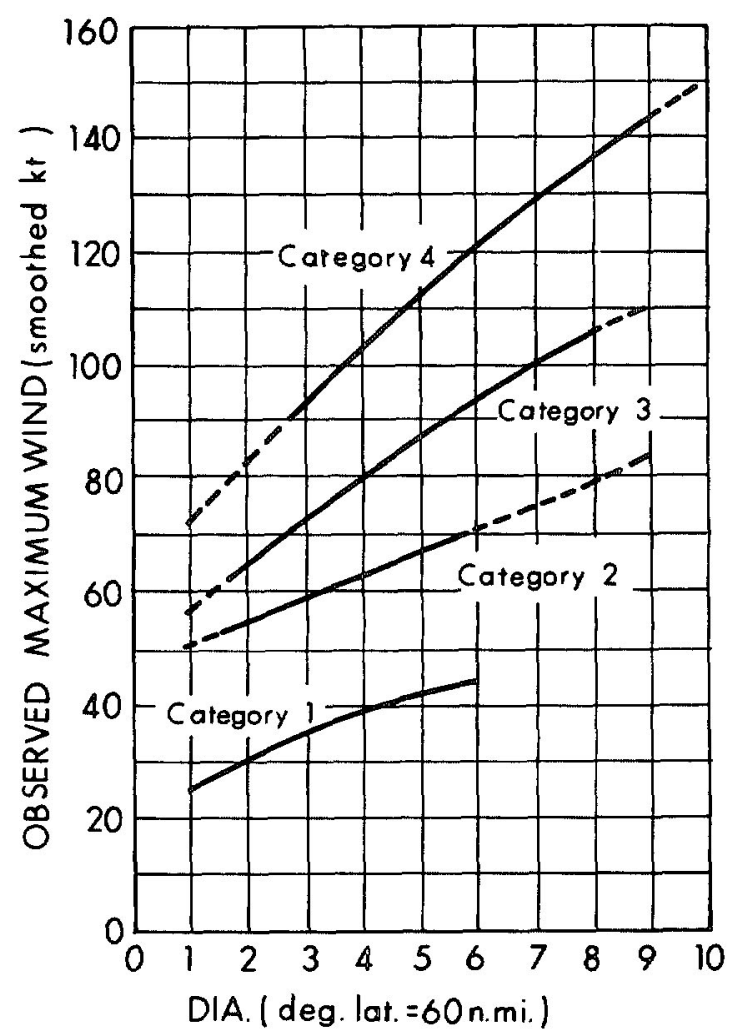

Figure 3.-Nomogram used to determine wind speeds in stage $X$ storms (after Bittner 1967).

storm. Thus, the gradient of pressure was $\approx 6 \mathrm{mb}$ in $30 \mathrm{n}$. mi. (adjusted for deepening of $1 \mathrm{mb} / \mathrm{hr}$ ).

By use of the gradient wind equation with the observed pressure gradient and radius of curvature, we obtain a computed wind speed of $\approx 65 \mathrm{kt}$-in excellent agreement with the observed wind. The minimum pressure of $1001 \mathrm{mb}$ ( 29.56 in.) reported by Hotel normally is sufficiently low to support a system of tropical storm strength, and, considering the small size of this particular system, suggests a storm of minimal hurricane strength.

After the eye of the storm passed near Hotel at 0310 GMT, gales from the west and northwest occurred at the ship until $0600 \mathrm{GMT}$, indicating a well-developed circulation that included the southwest quadrant. (In its earlier history, when the storm passed north of Puerto Rico, gales were confined to the north of the center with only light winds to the south.) The pressure at the ship rose very rapidly from the $1001-\mathrm{mb}$ (29.56-in.) minimum at $0310 \mathrm{GMT}$ to $1008.5 \mathrm{mb}(29.78 \mathrm{in}$.) at $0400 \mathrm{GMT}$, a $7.5-\mathrm{mb}$ rise in $50 \mathrm{~min}$.

Satellite pictures near noon on August 18 (fig. 2) show a well-defined eye near $41.5^{\circ} \mathrm{N}, 61.6^{\circ} \mathrm{W}$ at 1545 GMT. The National Environmental Satellite Service (NESS) Tropical Disturbance Bulletin for that day classified the storm as stage $\mathrm{X}$, category 3 (a "bright central overcast that is compact and tends to be circular," see Anderson et al. 1969 for details). The diameter of the cloud mass was $\approx 3^{\circ}$ of latitude. An empirically derived nomogram relating category and diameter of cloud mass to maximum wind 


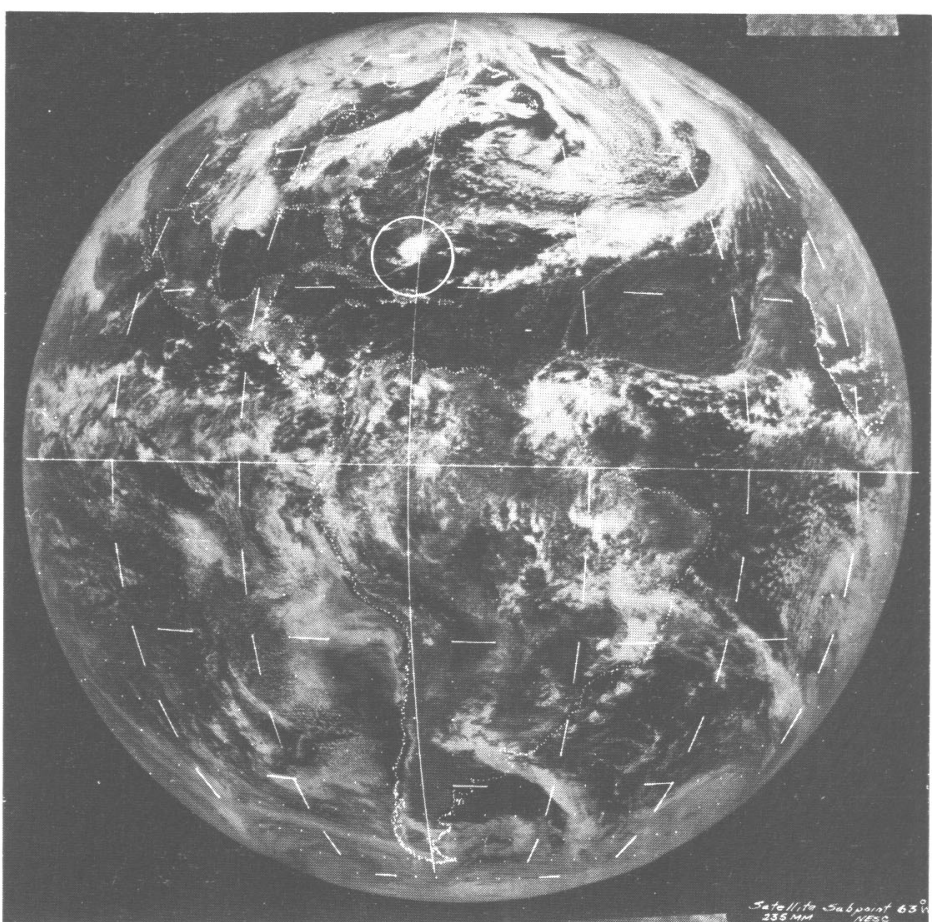

Figure 4.-ATS 3 satellite picture, Western Hemisphere, 1605 GMT, Oct. 11, 1970.

speed is shown in figure 3 (after Bittner 1967). For this case it would give a maximum wind of $\approx 74 \mathrm{kt}(85 \mathrm{mi} / \mathrm{hr})$. Figure 2 also shows that the cold frontal cloud band that had moved off the northeast coast of the United States was in the process of merging with the hurricane. By 0000 GMT, August 19, the storm had lost most of its tropical characteristics, but had a central pressure of $990 \mathrm{mb}$ (29.24 in.) near $45^{\circ} \mathrm{N}, 55^{\circ} \mathrm{W}$. It was still generating gales as evidenced by a report of $50-\mathrm{kt}$ southerly winds from the Irkoutsk near $43^{\circ} \mathrm{N}, 53^{\circ} \mathrm{W}$ (U.S. Department of Commerce 1970).

\section{UNNAMED STORM NO. 2-OCT. 12-17, 1970}

Satellite pictures indicated that a tropical depression had formed north of Hispaniola on Sunday, Oct. 11, 1970, near latitude $24^{\circ} \mathrm{N}$ and $71^{\circ} \mathrm{W}$ (fig. 4). The depression drifted slowly eastward for the next 2 days. Figures 5 and 6 show the surface analyses at $1200 \mathrm{GMT}$ on October 12 and 13 , and figures 7 and 8 show ATS 3 satellite pictures taken both days around 1600 GMT (1100 EST). During this 2-day period, central pressure of the system was steady between 1004 and $1005 \mathrm{mb}$ (29.65 and $29.68 \mathrm{in}$.). The satellite pictures suggest that the cloud mass associated with the depression merged with a cloud mass associated with an old, very weak stationary front along $26^{\circ}-27^{\circ} \mathrm{N}$ latitude by October 13. At this stage in its history, the low-pressure system was no longer purely tropical; rather, it might be termed "semitropical." At present, the semitropical cyclone is not recognized by meteorolcgists as a separate

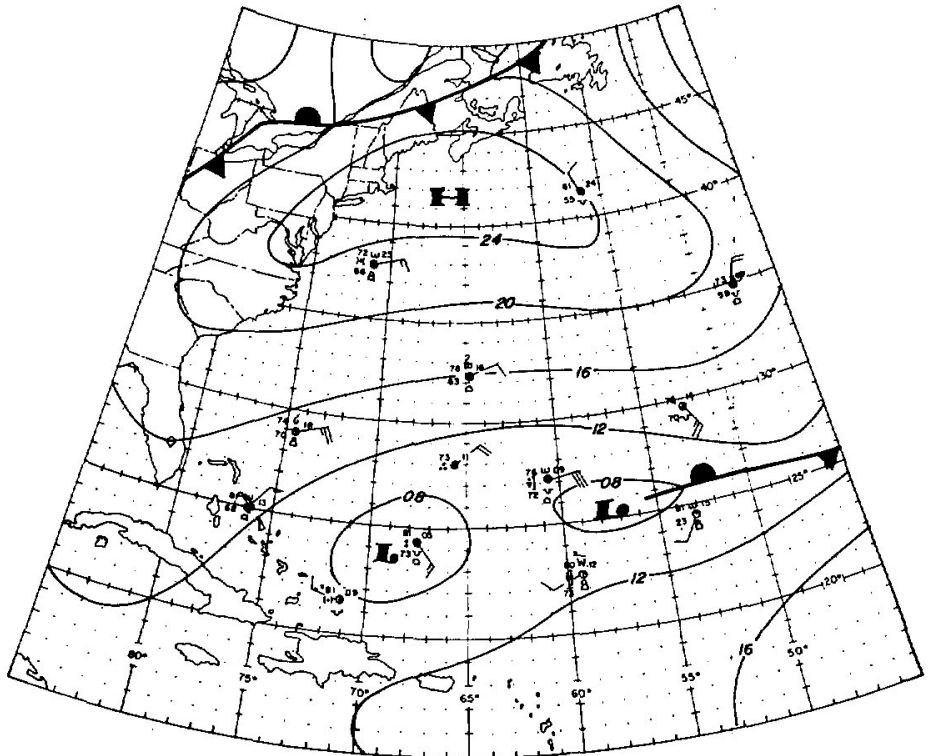

Figure 5.-Surface analysis, western Atlantic and Caribbean Sea, 1200 GMT, Oct. 12, 1970.

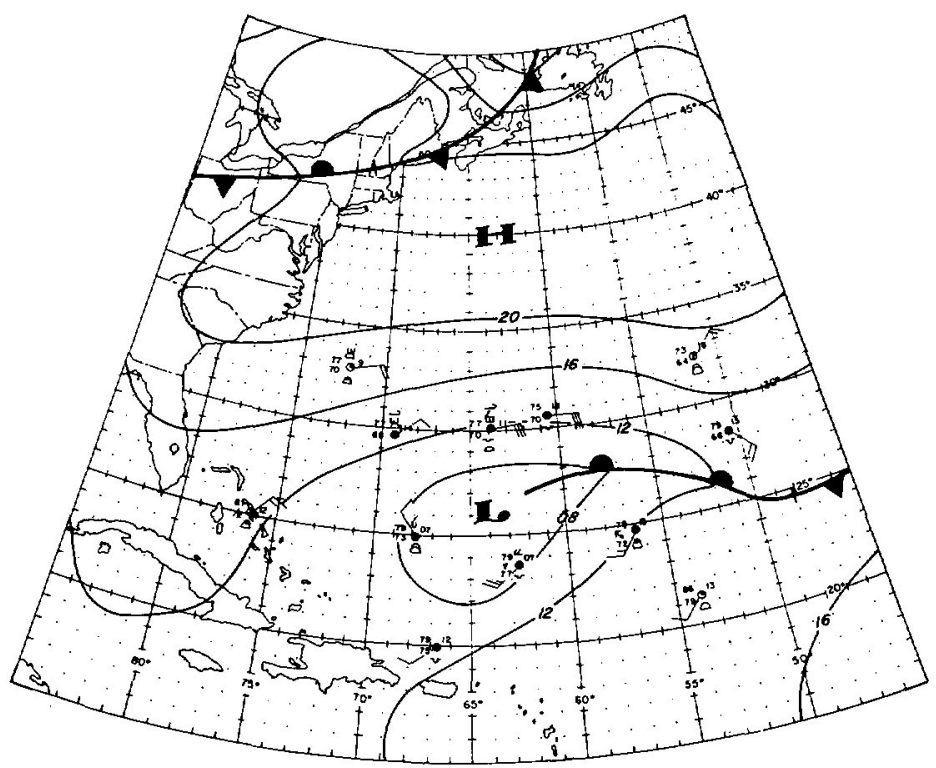

Figure 6.- Surface analysis, western Atlantic and Caribbean Sea, 1200 GMT, Oct. 13, 1970.

class of cyclones. We have tended, in the past, to place these storms into one of the three basic recognized types of cyclones; that is, the classical extratropical wave cyclone, the tropical cyclone, and the subtropical or "Kona" cyclone described in detail by Simpson (1952) and Ramage (1961). The cyclone in the southwest North Atlantic was classified as a "subtropic storm" of the Kona type by the NHC on Wednesday, October 14, as it began to drift westward and intensify. However, careful analysis of the available data and comparison with the subtropical (yclone model do not appear to support this conclusion.

The National Meteorological Center (NMC) surface analysis for $1200 \mathrm{GMT}$ (0700 EST) October 14 (fg. 9) in- 


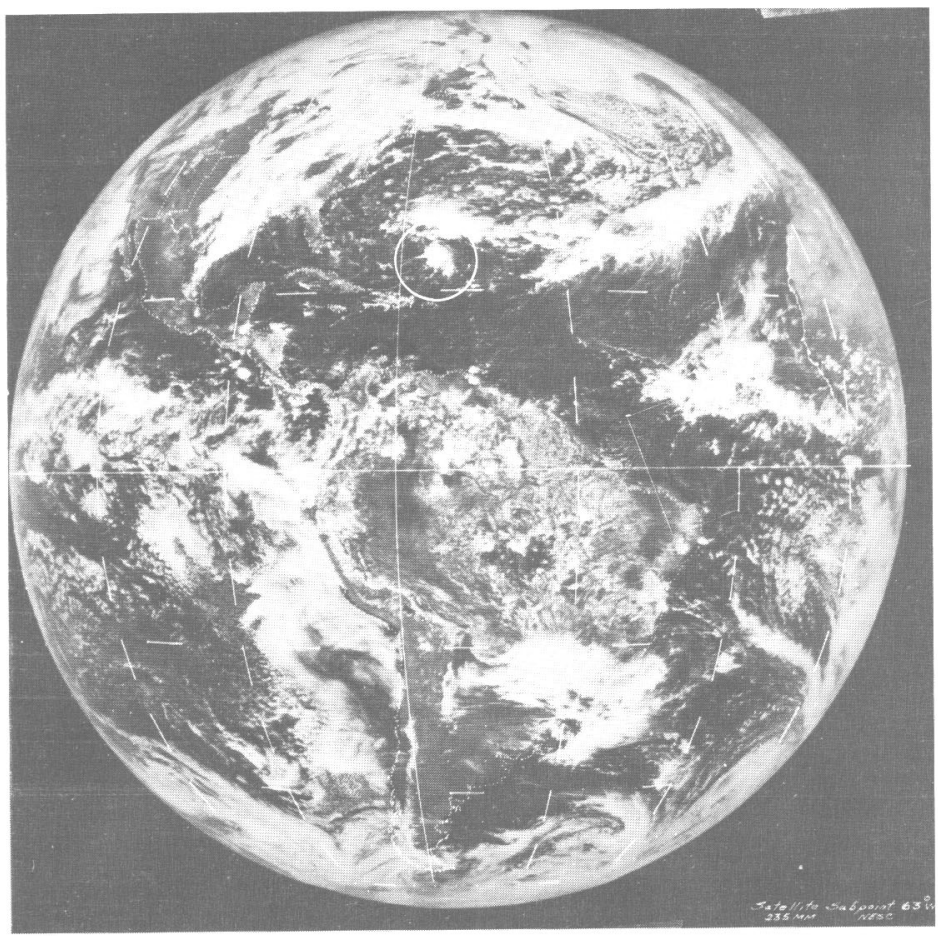

Figure 7.-ATS 3 satellite picture, Western Hemisphere, 1608 Gmт, Oct. $12,1970$.

dicates that the Low is near $26.8^{\circ} \mathrm{N}$ and $67.0^{\circ} \mathrm{W}$ with central pressure $1000 \mathrm{mb}$ (29.53 in.). Ship reports in the immediate vicinity of the cyclone indicate the air mass to be tropical and homogeneous with respect to surface temperature and dewpoint; temperatures are about $79^{\circ} \mathrm{F}$ and dewpoints in the low $70 \mathrm{~s}$ north, west, and south of the storm center. Further north of the storm, between $30^{\circ}$ and $35^{\circ} \mathrm{N}$, surface temperatures were in the middle $70 \mathrm{~s}$ and dewpoints in the $65^{\circ}-70^{\circ} \mathrm{F}$ range-indicative of greatly modified air of polar maritime origin gradually becoming more maritime tropical. Thus, the northern periphery of the cyclonic circulation was in a weakly baroclinic zone.

ATS 3 satellite pictures taken every $25 \mathrm{~min}$ or so show that the cloud pattern grows somewhat larger and more organized throughout the day (cf. figs. $10 \mathrm{~A}, 10 \mathrm{~B}$, and $10 \mathrm{C}$ ).

$\mathrm{Navy}$ reconnaissance aircraft investigating the cyclone reported maximum surface winds estimated at $65 \mathrm{kt}$ (minimal hurricane force) at a distance of 35 n.mi. from the center and a central pressure of $999 \mathrm{mb}$ ( $29.50 \mathrm{in}$.) at 1725 GMT, October 14. Maximum flight level $(150 \mathrm{~m})$ winds were reported to be $55 \mathrm{kt}, 35 \mathrm{n}$.mi. northwest of the center. The flight summary also indicated that the "eye appears closed visually with wall clouds all quadrants." The size of the eye was "estimated as 20 n.mi." The cyclone did not qualify as a tropical storm at this time because the temperature dropped $2^{\circ} \mathrm{C}$ from $23^{\circ}$ to $21^{\circ} \mathrm{C}$ at $150-\mathrm{m}$ level from outside the center to the center (aireraft report); that is the system did not have the warm core structure typical of tropical storms, at least in the lowest levels.

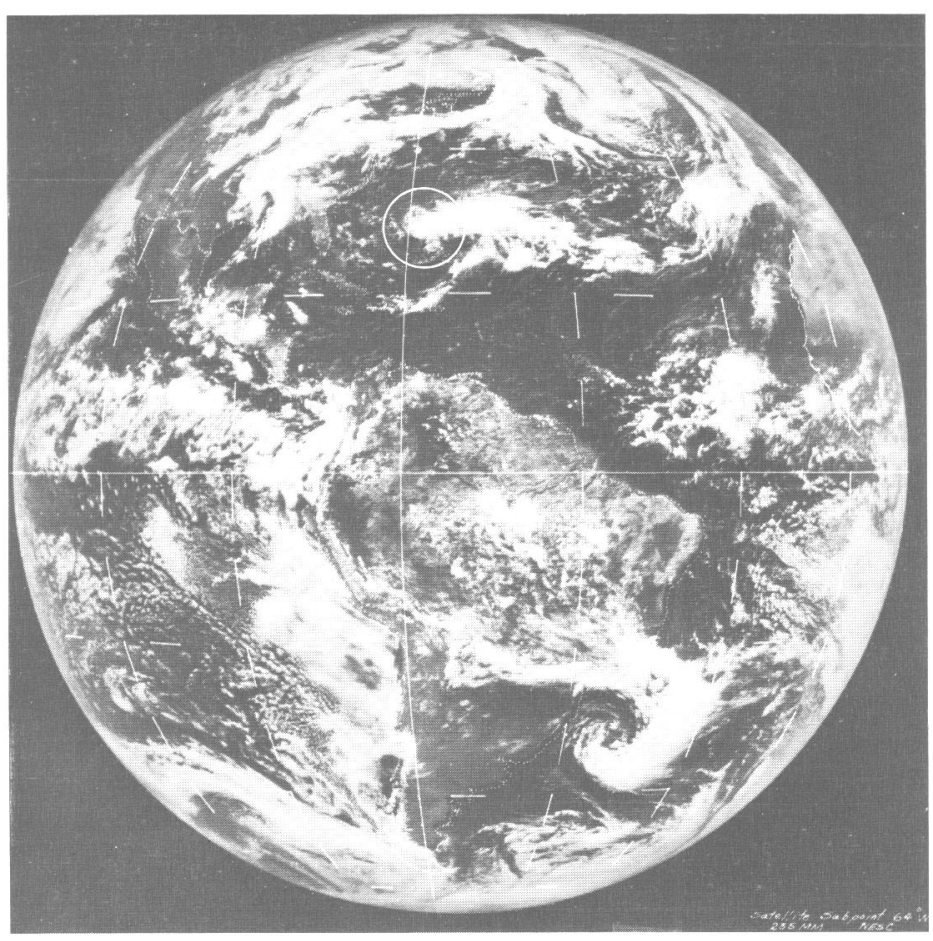

Figure 8.-ATS 3 satellite picture, Western Hemisphere, 1540 GMT, Oct. 13, 1970.

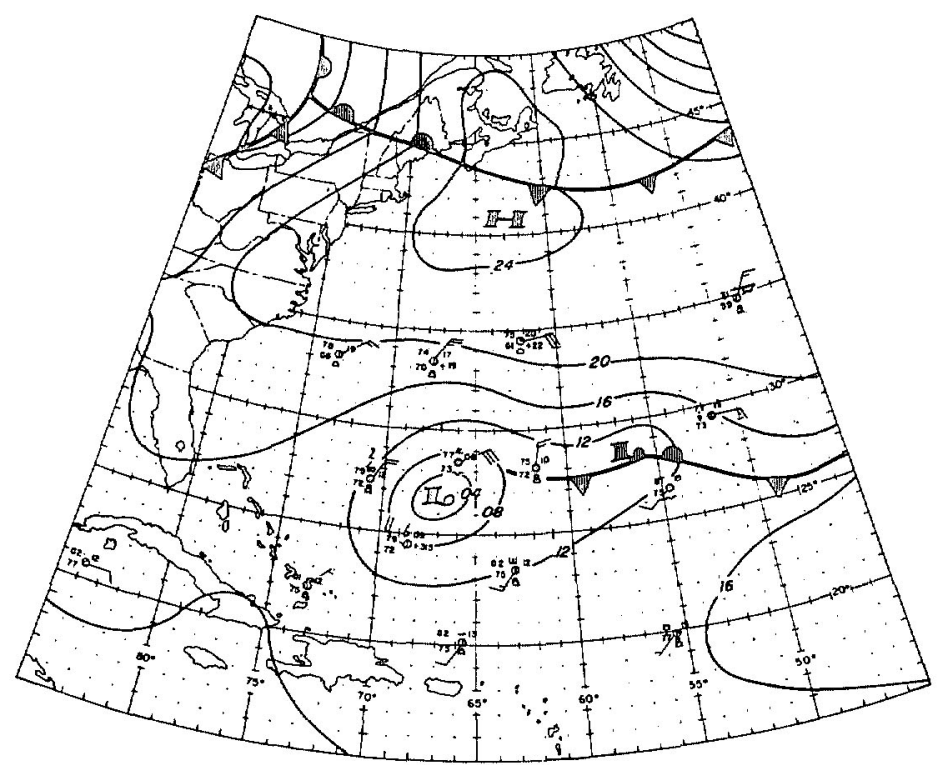

Figure 9.-Surface analysis, western Atlantic and Caribbean Sea, 1200 Gмт, Oct. 14, 1970.

It is apparent from the relative homogeneity of the air mass (1200 GMT, October 14), as discussed above, that the low-pressure system was not an extratropical wave cyclone. While the system might have resembled the subtropic cyclone in some respects, one can develop a convincing rationale for not typing it as a subtropic cyclone.

Simpson (1952) describes in some detail two sources of cyclogenesis for the subtropic cyclone. Development can occur when (1) an "occluded [extratropical] cyclone be- 

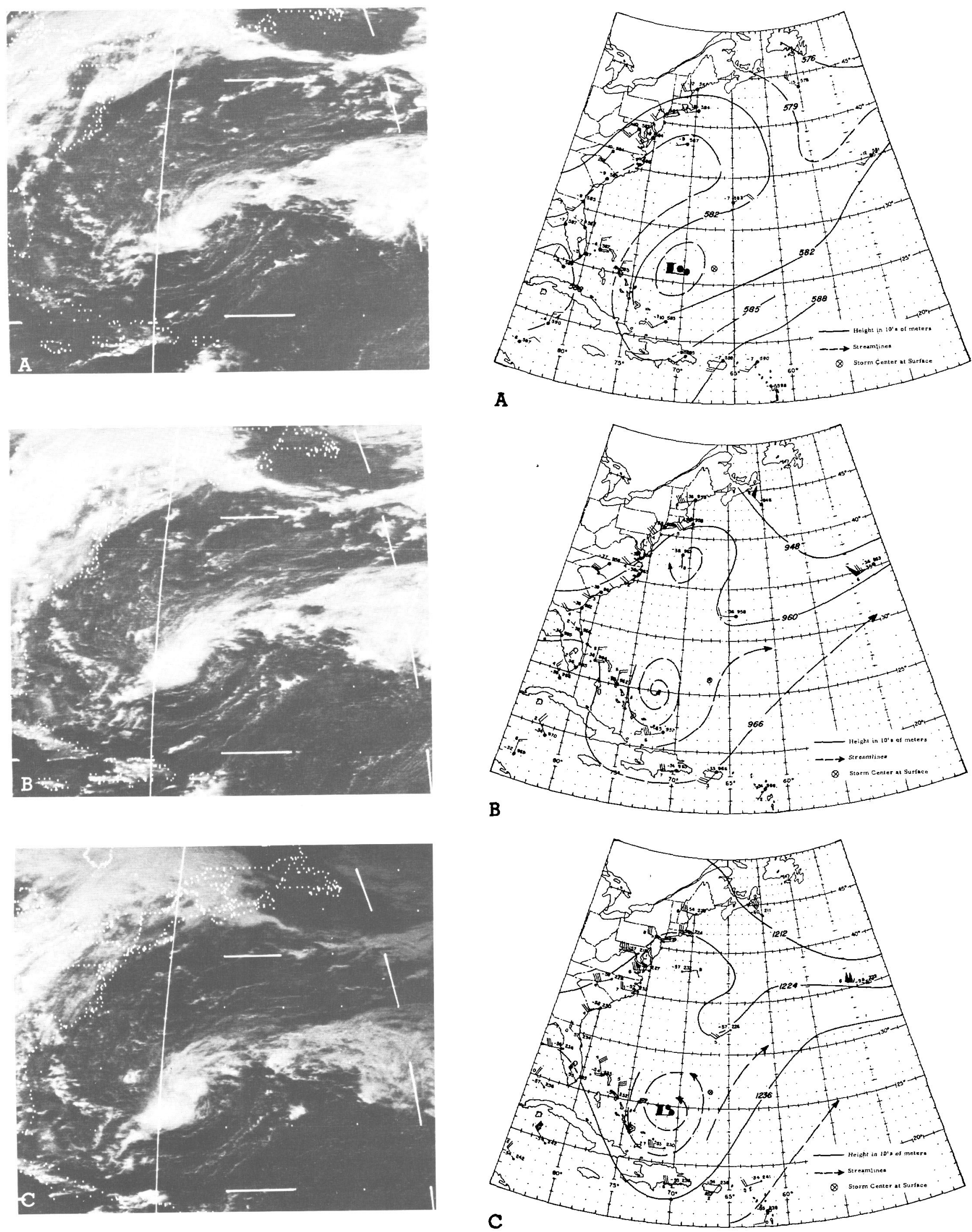

Figure 10.-ATS 3 satellite pictures, western Atlantic, Oct. 14, 1970: (A) 1357, (B) 1634, (C) 1910 GMT.

Figure 11.-Constant pressure analyses, western Atlantic and Caribbean Sea, $1200 \mathrm{GMT}$, Oct. 14, 1970: (A) 500, (B) 300, (C) $200 \mathrm{mb}$. 
TABLE 3.-Aircraft reconnaissance reports during the Oct. 14-17, 1970, Atlantic hurricane

\begin{tabular}{|c|c|c|c|c|c|c|c|c|c|c|c|}
\hline Date & Time & $\begin{array}{l}\text { Latitude } \\
\text { deg. min }\end{array}$ & $\begin{array}{l}\text { Longitude } \\
\text { deg. min }\end{array}$ & $\begin{array}{l}\text { Max. } \\
\text { surface } \\
\text { wind }\end{array}$ & $\begin{array}{l}\text { Direction \& } \\
\text { distance of } \\
\text { max. wind } \\
\text { from center }\end{array}$ & $\begin{array}{l}\text { Temp. } \\
\text { outside }\end{array}$ & $\begin{array}{l}\text { Temp. } \\
\text { inside }\end{array}$ & $\begin{array}{l}\text { Central } \\
\text { pressure }\end{array}$ & $\begin{array}{l}\text { Flight } \\
\text { level }\end{array}$ & Eye configuration, diameter & Remarks \\
\hline$(1970)$ & (GMr) & (north) & (west) & $(\mathbf{k t})$ & $(\mathrm{deg} . / \mathrm{n} . \mathrm{mi})$ & $\left({ }^{\circ} \mathrm{C}\right)$ & $\left({ }^{\circ} \mathrm{C}\right)$ & $(\mathrm{mb})$ & $(\mathrm{m})$ & (n. mi.) & \\
\hline Oct. 14 & 1725 & $27^{\circ} 26^{\prime}$ & $67^{\circ} 22^{\prime}$ & 65 & $320 / 35$ & 23 & 21 & 999 & 150 & Unknown 20 & Eye closed, wall clouds all quads. \\
\hline Oct. 15 & 1204 & $28^{\circ} 06^{\prime}$ & $67^{\circ} 24^{\prime}$ & 45 & $240 / 30$ & 25 & 24 & 995 & 40 & Circular 20, poorly defined & $\begin{array}{l}\text { Wind only observed in SW quad., } \\
\text { apparent strong eyewall } \mathrm{N} \text {. }\end{array}$ \\
\hline Oct. 15 & 1304 & $28^{\circ} 06^{\prime}$ & $67^{\circ} 24^{\prime}$ & 65 & - & - & - & - & $?$ & - & Maximum surface wind $\mathrm{N}$ quad. \\
\hline Oct. 15 & 1750 & $29^{\circ} 00^{\prime}$ & $67^{\circ} 22^{\prime}$ & - & - & $\mathbf{M}$ & 23 & 994 & - & Circular 25 , poorly defined & $\begin{array}{l}\text { Most cloud tops } 7,000-10,000 \text { ft } \mathrm{S} \\
\text { quad., few buildups NE quad. }\end{array}$ \\
\hline Oct. 15 & 2010 & $29^{\circ} 21^{\prime}$ & $67^{\circ} 40^{r}$ & 65 & $330 / 35$ & 20 & 22 & 992 & $?$ & Circular 25 , poorly defined & Few buildups $\mathrm{N}$ quad. \\
\hline Oct. 16 & 0603 & $30^{\circ} 24^{\prime}$ & $66^{\circ} 24^{\prime}$ & $\mathbf{M}^{*}$ & $\mathbf{M}$ & 8 & 10 & $\mathbf{M}$ & 2896 & $\begin{array}{l}\text { Circular } 40 \text {, eyewall open } \\
\text { NW and } s\end{array}$ & \\
\hline Oct. 16 & 0728 & $30^{\circ} 33^{\prime}$ & $66^{\circ} 35^{\prime}$ & $\mathbf{M}$ & $\mathbf{M}$ & $\mathbf{M}$ & $\mathbf{M}$ & $\mathbf{M}$ & 2956 & - & $\begin{array}{l}\text { Cloud-filled with low clouds, feeder } \\
\text { bands } N \text { through SW. }\end{array}$ \\
\hline Oct. 16 & 1203 & $31^{\circ} 24^{\prime}$ & $66^{\circ} 00^{\prime}$ & 60 & $220 / 25$ & 9 & 11 & 989 & - & Circular 40 & Eye filled with low clouds. \\
\hline Oct. 16 & 1920 & $32^{\circ} 50^{\prime}$ & $64^{\circ} 14^{\prime}$ & 70 & $220 / 25$ & $\mathbf{M}$ & $\mathbf{M}$ & 982 & - & - & \\
\hline Oct. 16 & 2026 & $33^{\circ} 07^{\prime}$ & $64^{\circ} 02^{\prime}$ & 75 & $270 / 25$ & 22 & 23 & 980 & 150 & Circular 26 , break south wall & $\begin{array}{l}\text { Eye well defined, apparent move- } \\
\text { ment } 030^{\circ} \text { at } 20 \mathrm{kt} \text {. }\end{array}$ \\
\hline Oct. 16 & 2340 & $33^{\circ} 50^{\prime}$ & $63^{\circ} 29^{\prime}$ & $50 \dagger$ & $160 / 30$ & 6 & 13 & 983 & 2940 & Circular 26, well defined & $\begin{array}{l}\text { Solid cloud all quads., occastonal } \\
\text { breaks } \mathrm{S} \text {. }\end{array}$ \\
\hline Oct. 17 & 0715 & $36^{\circ} 40^{\prime}$ & $61^{\circ} 00^{\prime}$ & $55 \dagger$ & $020 / 09$ & 8 & 14 & 974 & $2938 / 28$ & $\begin{array}{l}\text { Elliptical, well defined (major } \\
\text { axis N-S) }\end{array}$ & $\begin{array}{l}\text { Eye appears to slope to } \mathrm{N} \text {, several } \\
\text { breaks in wall clouds. }\end{array}$ \\
\hline Oct. 17 & 1020 & $38^{\circ} 00^{\prime}$ & $60^{\circ} 18^{\prime}$ & 60 & $190 / 30$ & 7 & 12 & $\mathbf{M}$ & - & Circular 10, well defined & $\begin{array}{l}\text { 700-mb center displaced } \mathrm{NE} \text { of } \\
\text { surface. }\end{array}$ \\
\hline Oct. 17 & 1130 & $38^{\circ} 36^{\prime}$ & $60^{\circ} 54^{\prime}$ & $90 \dagger$ & $190 / 35$ & 7 & 12 & 975 & - & Circular 15, well defined & $\begin{array}{l}\text { Few breaks in wall clouds } S W \text {, solid } \\
\text { wall cloud. }\end{array}$ \\
\hline
\end{tabular}

${ }^{*} M$ represents missing data.

tMaximum wind at fight level.

comes trapped at low latitudes by the blocking action of a warm high" or (2) "cold lows aloft . . . extend their circulations gradually to the surface."

The sequence of events leading to the cyclogenesis in this case was obviously not the first of these processes (see figs. 4-9). The formation and intensification of the sea-level cyclone was probably not due to the presence of a well-defined low aloft extending its influence to the surface either, because only a weak Low aloft, if any, was evident from the analyses for October 12 and 13. The mid and upper tropospheric synoptic patterns for 1200 GMT on October 14 are shown in figures $11 \mathrm{~A}, 11 \mathrm{~B}$, and $11 \mathrm{C}$. The 500-mb analysis shows a trough with the suggestion of a Low center to the west of the position of the sea-level cyclone. The 300 - and $200-\mathrm{mb}$ analyses strongly suggest that intensification of the sea-level cyclone on October 14 was due, in part, to high-level divergence causing outflow over the cyclone and a compensating convergence and inflow with pressure falls at low levels. This mechanism has been suggested by Riehl (1954) and others as one possible cause of the deepening of tropical cyclones. Another part of the deepening may be attributed to release of latent heat of condensation in the convective regions of the cyclone.

The original model for the subtropic cyclone characteristics shows the maximum winds to be from $200 \mathrm{mi}$ (174 n.mi.) to as much as $500 \mathrm{mi}$ (434 n.mi.) from the center, with relatively light winds $50-100 \mathrm{mi}(43-87 \mathrm{n} . \mathrm{mi}$.) from the center.

On Oct. 14, 1970, the aircraft reported the maximum wind to be $25 \mathrm{n} . \mathrm{mi}$. from the center. Thus, both the maximum wind distribution and the formation of the cyclone apparently do not conform to the subtropic cyclone model.

On Thursday, October 15, aircraft reconnaissance, satellite pictures, and ship reports all indicated that the cyclone had intensified to near hurricane strength. Table 3 summarizes the aircraft "detailed center messages" (transmitted on weather Teletype circuit " $O$ ") for the history of the storm. The data indicate that the storm drifted slightly west of due north at $4-9 \mathrm{kt}$ on the $15 \mathrm{th}$. Central pressure dropped slowly through the day to 992 $\mathrm{mb}$ (29.29 in.) and maximum winds reported by the aircraft were $65 \mathrm{kt}$-minimal hurricane force. This does not necessarily mean the storm was a hurricane all day; the thermal structure was apparently undergoing transition throughout the day.

The NHC, monitoring the storm's progress, referred to the storm as a "severe subtropic winter-type storm" in their special bulletins during the day (October. 15) adding in the 2230 GMT (1730 EST) bulletin that "the cool central core of the system which is common in winter storms is warming and the structure is gradually acquiring the characteristics that are typical of a hurricane." Simpson (1952) and Ramage (1961) both indicate that the subtropic storm may at times evolve into a tropical cyclone. As can be seen in table 3, temperature data outside the core of the storm were missing part of the day. The only outside and inside temperatures reported were at 1204 GMT at the $40-\mathrm{m}$ level, showing the outside temperature $1^{\circ} \mathrm{C}$ higher than inside and at 2010 GMT showing the reverse; that is, a warming of $2^{\circ} \mathrm{C}$ from outside into the center. The 500-mb chart from NMC for $1200 \mathrm{GMT}$, October 15 (fig. 12), shows a warm core at that level as 


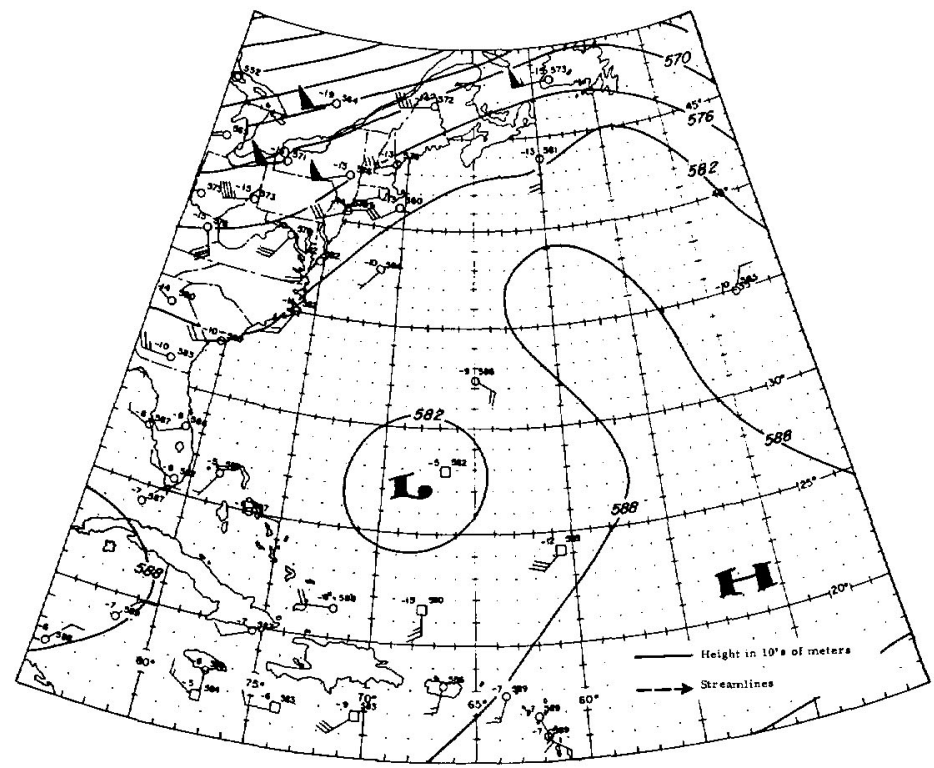

Figure 12.-The 500-mb analysis, western Atlantic and Caribbean Sea, 1200 Gмт, Oct. 15, 1970.

determined from the Air Weather Service reconnaissance (Gull) flight that morning $\left(-5^{\circ} \mathrm{C}\right.$ near the center of the Low ; $-8^{\circ}$ to $-13^{\circ} \mathrm{C}$ reported on the outside periphery of the Low). While there may have been some doubt as to the exact thermal structure on October 15, the trend was, as the NHC bulletin stated, toward warming. Maximum winds again were $\approx 65 \mathrm{kt}$ within $35 \mathrm{n}$.mi. of the center.

Satellite pictures of tropical storms are well documented (e.g., Fritz et al. 1966) and the ATS 3 satellite pictures provide striking evidence that the storm had characteristics typical of tropical storms (figs. 13A through 13C). The cloud pattern throughout the day (October 15) closely resembles that for a stage $X$, category 2 tropical disturbance (Anderson et al. 1969). Strong convection is evident to the north of the center. A movie loop composed of ATS 3 pictures taken at 25- to 30-min intervals shows feeder bands of strong convection, typical of organized tropical storms, flowing into the storm's circulation.

By Friday morning, October 16, satellite pictures (fig. 14) depicted a cloud pattern typical of tropical hurricanes including an eye, and aircraft reports (table 3) indicated a warm core at the $700-\mathrm{mb}$ level and central pressure of 989 $\mathrm{mb}(29.20 \mathrm{in}$.). These would necessarily lead to the conclusion that the storm was tropical in character and of near hurricane intensity. (Surface dewpoints were in the 70 s north of the storm to near $40^{\circ} \mathrm{N}$.) References to the cyclone contained in the bulletins from the NHC on Friday, October 16, were to a "severe storm" and the "large Atlantic storm"- the term "subtropic cyclone" was not used in these bulletins. During the day, the hurricane moved in a north-northeasterly direction at an increasing forward speed, passing just to the west of Bermuda at about 1800 GMT (1300 EST). Highest winds observed at Bermuda were $42 \mathrm{kt}$ with gusts to $50 \mathrm{kt}$ as the storm passed. Radar reports from Bermuda indicated spiral
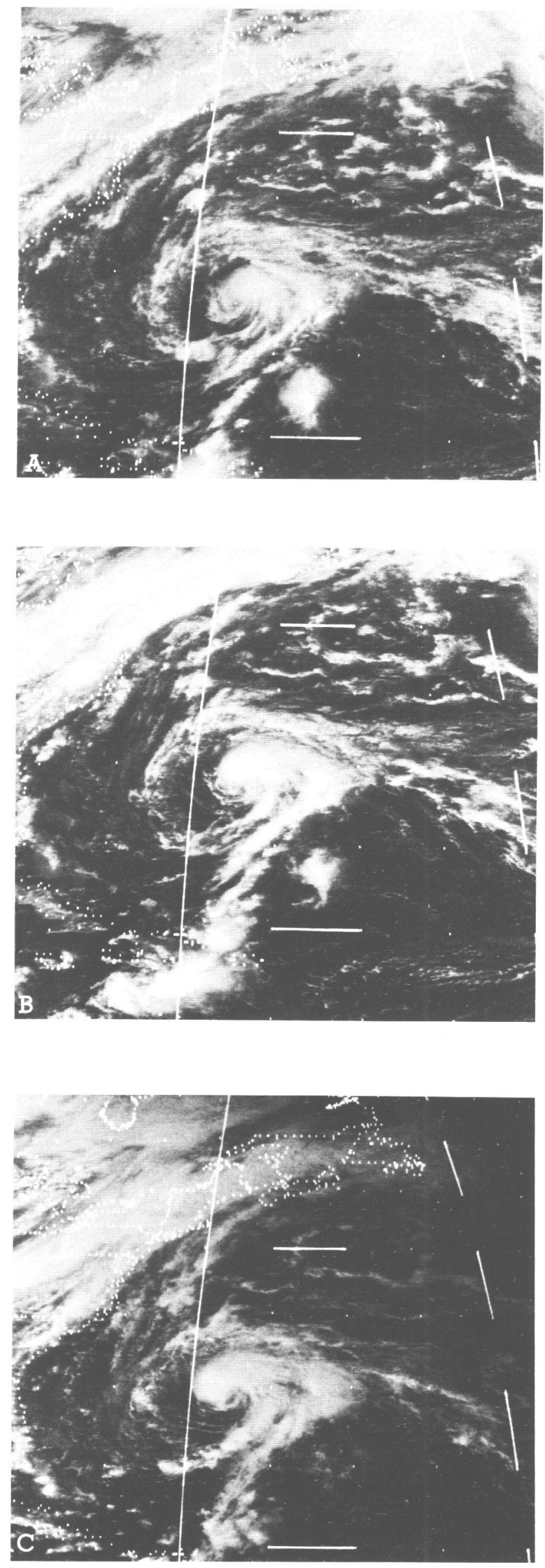

Figure 13.-ATS 3 satellite pictures, western Atlantic, Oct. 15, 1970: (A) 1403, (B) 1613, (C) 1942 Gмт. 


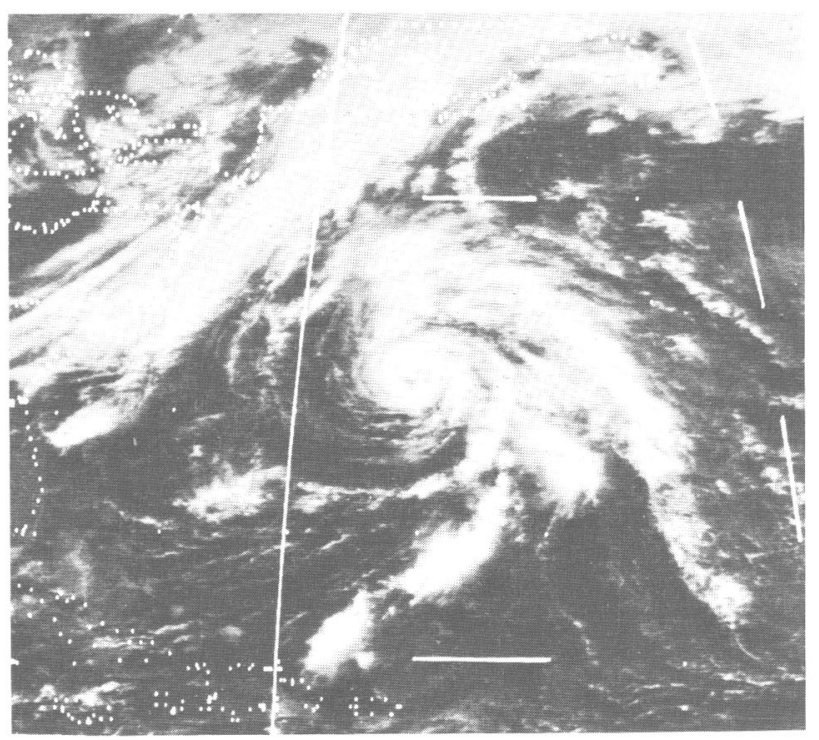

FIGURE 14.-ATS 3 satellite picture, western Atlantic, 1406 GMT, Oct. 16, 1970.

band areas and an eye throughout the day. Simpson and Pelissier (1971) report that "an anemometer at a $100-\mathrm{ft}$ elevation at NASA station Bermuda recorded a maximum [wind] reading of 87 knots."

The warming at the core of the storm (probably caused by release of latent heat of condensation associated with strong convection) continued until Saturday morning, October 17 (table 3 ), with a $700-\mathrm{mb}$ temperature increase of $7^{\circ} \mathrm{C}$ (from $6^{\circ}$ to $13^{\circ} \mathrm{C}$ ) from the outside to inside the eye at 2340 GMT, October 16 , and an increase from $8^{\circ}$ to $14^{\circ} \mathrm{C}$ (outside to inside the eye) at $0715 \mathrm{GMT}$, October 17. These reports leave little doubt that the structure was warm core for at least $30-36 \mathrm{hr}$. Jordan (1957b) has developed mean soundings for the hurricane eye from a collection of aircraft dropsonde reports. The mean soundings show that a $700-\mathrm{mb}$ temperature of $12.1^{\circ} \mathrm{C}$ is characteristic of the eye of a weak hurricane and a $700-\mathrm{mb}$ temperature of $14.4^{\circ} \mathrm{C}$ is associated with a moderate hurricane. For comparison, the mean tropical atmosphere has a temperature of $7.9^{\circ} \mathrm{C}$ at $700 \mathrm{mb}$ (Jordan 1957a). Based on the above information and the actual temperature and wind data associated with the unnamed hurricane of October 1970, one would place the hurricane in the weak category throughout most of its life. On the morning of October 17 , the $14^{\circ} \mathrm{C}$ temperature and the $90-\mathrm{kt}$ wind observed at the $700-\mathrm{mb}$ level suggest that the hurricane may have been in the moderate category for a brief period.

By October 17, the hurricane was accelerating northnortheastward. A radio NSS (Washington, D.C.) bulletin at 1200 GMT stated "the severe storm center 300 miles northeast of Bermuda ... has hurricane characteristics. The storm should begin to lose tropical characteristics as it moves northward over colder water."

ATS 3 satellite pictures taken early in the day on the 17 th show the hurricane vortex well defined near $40^{\circ} \mathrm{N}$,

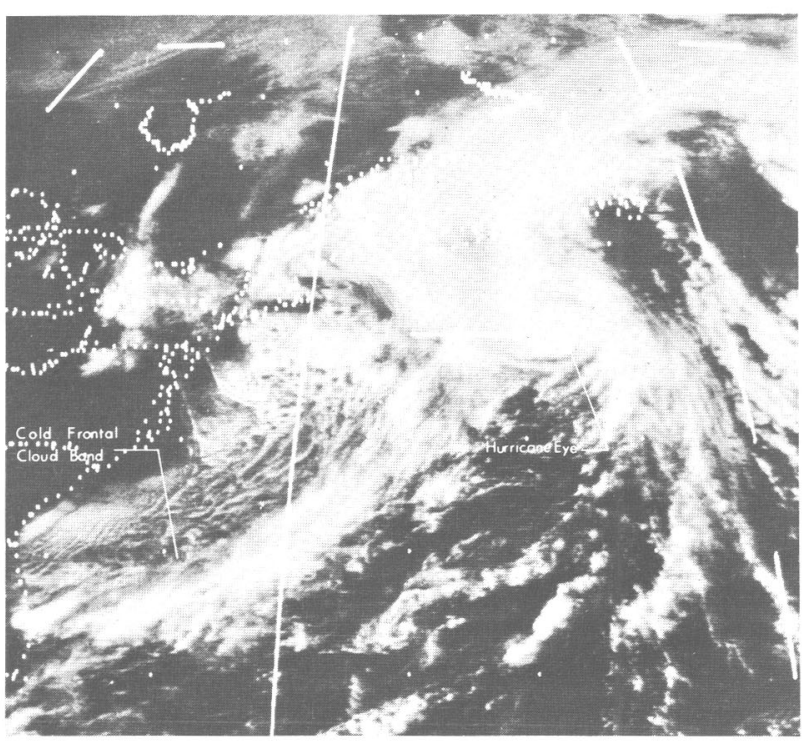

FIGURe 15.-ATS 3 satellite picture, western Atlantic, 1426 GMT, Oct. $17,1970$.

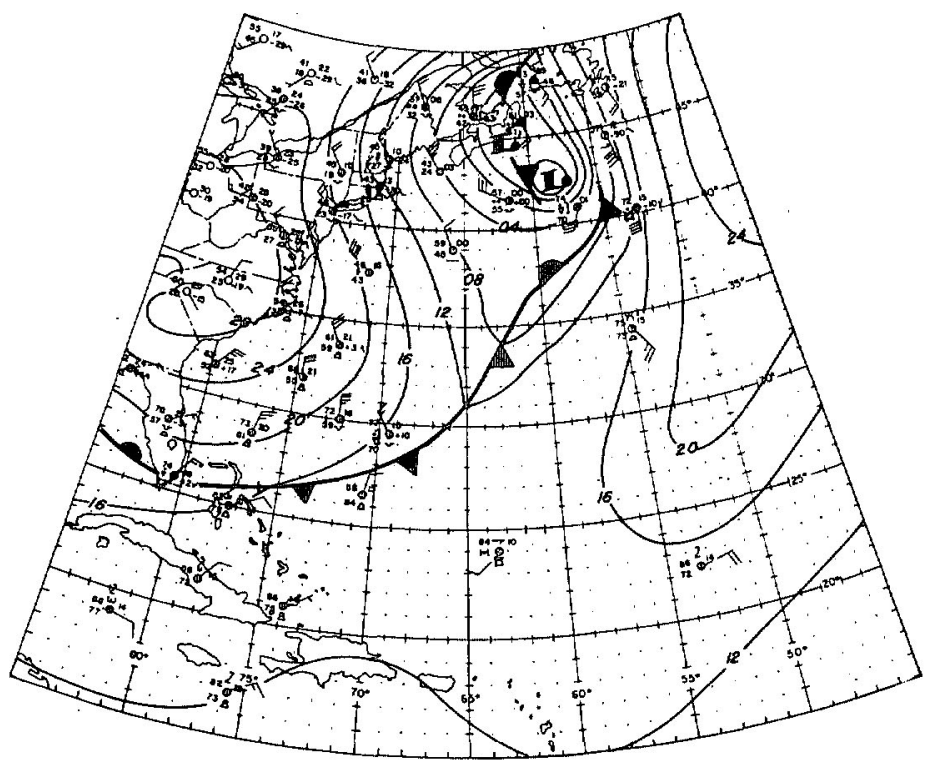

Figure 16.-Surface analysis, western Atlantic, 1800 GMT, Oct. 17, 1970.

$60^{\circ} \mathrm{W}$ (fig. 15). To the west of the hurricane, a strong cold front was approaching as evidenced by the broad cloud band off the east coast of the United States. By $1800 \mathrm{GMT}$, the cold front was entering the hurricane circulation and the storm began to lose its tropical characteristics (fig. 16).

The above presentation of satellite, conventional, and aircraft reconnaissance data leads to the inescapable conclusion that the Atlantic cyclone of October 12-17 was a true tropical hurricane on October 16 and 17 (until 1800 GMT) and may have been a hurricane as early as the afternoon of October 15. The tracks of both of the unnamed Atlantic hurricanes of 1970 during various stages in their life cycles appear in figure 17. 


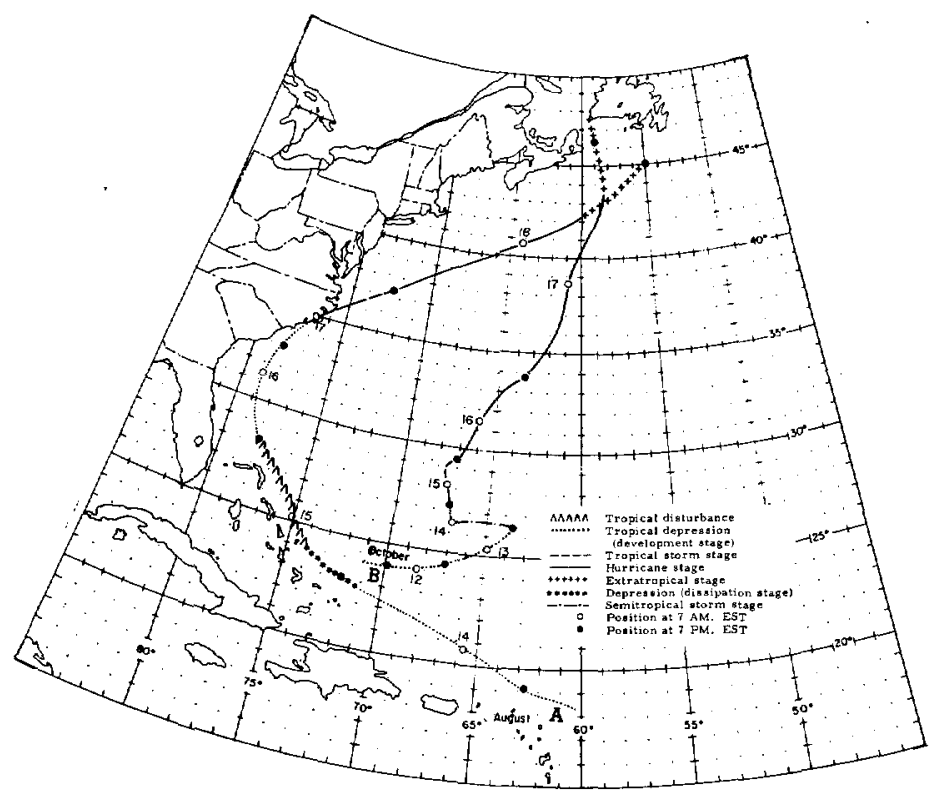

Figure 17.-Tracks of unnamed 1970 hurricanes: (A) August, (B) Cctober.

\section{SUMMARY AND CONCLUSIONS}

Careful analysis of satellite, aircraft, radar, and conventional data for two unnamed cyclones that occurred in the Atlantic during the 1970 hurricane season provides persuasive evidence for concluding that the cyclones were tropical storms of hurricane intensity for part of their life history. In the case of the first cyclone (August 13-18), ship, radar, satellite, and conventional data clearly indicate that the cyclone had tropical characteristics, was of tropical storm intensity for about $18 \mathrm{hr}$, and may have been of hurricane intensity for $\approx 12 \mathrm{hr}$.

For the second cyclone (October 12-18), there was no doubt that the intensity was sufficiently strong to qualify as a tropical storm and eventually a hurricane. In this case, the NHC referred to the storm as a "severe subtropic winter-type storm" of the Kona type described by Simpson (1952) and Ramage (1961). Temperature and wind data from aircraft reconnaissance flights indicated that it had the structure and characteristics typical of a strong tropical storm or hurricane on October 16 and 17 (warm core, and maximum winds of $65 \mathrm{kt}$ within 22-30 n. mi. of the center). Satellite pictures on those days confirmed that the storm was probably a hurricane in that the storm exhibited the cloud patterns and organization familiar by now as those associated with tropical hurricanes.

One of the more interesting aspects of the cyclone was its earlier history (October 12-14) when it was difficult to classify into any of the recognized types of cyclones; that is, the classical extratropical wave cyclone, the tropical cyclone, and the subtropic cyclone. On October 14, Dr. Robert Simpson, Director of the NHC, issued a bulletin referring to the cyclone as "a subtropical rather than a tropical system" and expanded on this in a bulletin the following morning when it was classified as a subtropic storm of the type known as a Kona storm in the eastern Pacific. While it may not have been a true tropical storm at this point in its history, the evidence presented earlier indicates that the cyclone apparently did not fit the subtropic cyclone model either.

Rather, the data indicate that the cyclone should have been classified as semitropical during October 14 and the morning of October 15. As mentioned earlier, the concept of the semitropical cyclone, although not completely new, is presently not widely accepted. Reference to this type of cyclone was contained in the summary of the 1963 hurricane season by Dunn and Staff (1964) in commenting on the unnamed storm of Sept. 10-15, 1963: "Each year several storms occur which are not entirely tropical in character. Tropical cyclones derive their energy from latent heat of condensation while extratropical storms depend [partly] upon proper positioning of cold and warm air masses; . . .. At times 'half-breed' cyclones develop over tropical oceans and tap both energy sources. In these cases, it is difficult to decide whether a tropical cyclone name should be assigned to the LOW."

Another reference to an apparent semitropical storm was made by Erickson (1967) in his detailed study on the development of hurricane Dorothy. Erickson presents convincing evidence that the formation and subsequent intensification of Dorothy were due to both tropical and extratropical energy sources. Later in its life Dorothy did develop a warm core and exhibited typical hurricane characteristics. Thus, it appears that the semitropical storm may at times evolve into a hurricane as Dorothy did and as did the unnamed hurricane of October 1970.

Simpson and Pelissier (1971) identify the two cyclones discussed in this paper as hybrid storms and refer to them as neuter cyclones, while also indicating that they might be considered as having had tropical characteristics during part of their existence.

The author believes that there is enough evidence from a study of the data in the early history of the unnamed October 1970 hurricane, the early history of hurricane Dorothy of 1967 , and from a preliminary analysis of several others currently being studied by the author to tentatively conclude that the semitropical cyclone warrants recognition as a separate cyclone type having the following characteristics:

1. The air mass within which development takes place is relatively homogeneous, greatly modified, polar maritime air becoming tropical.

2 . The mean temperature in the area of formation is somewhat lower at low and midtropospheric levels than the mean tropical atmosphere for that month.

3. The cyclonic circulation weakens with height.

4. Maximum winds of gale to minimal hurricane force occur near the center.

Characteristic (1) is different from the pure extratropical cyclone. Characteristic (2) is different from the tropical cyclone and characteristics (3) and (4) taken together are different from the subtropic (Kona) cyclone model. 
The author plans further studies to determine the characteristics of the semitropical cyclone and the processes that lead to semitropical cyclogenesis.

\section{ACKNOWLEDGMENTS}

The author is grateful to the Charting Branch of the National Meteorological Center (NMC) for supplying the NMC analyses for the October cyclone and also to the National Environmental Satellite Service for loan of ATS 3 movie loops taken during the period of the two cyclones.

Special thanks are also due Northeast Weather Services, Inc: Bedford, Mass, for allowing use of some of their data facilities; Bill Abbott of Allied Research Associates (ARA) for developing and printing the satellite pictures; Walter Smith (ARA) for drafting the figures; and Joyce Mulhern for typing the manuscript.

The weather log for ship Hotel was obtained from the National.. Climatic Center, Asheville, N.C.

\section{REFERENCES}

Anderson, Ralph K., et al., "Application of Meteorological Satellite Data in Analysis and Forecasting," AWS Technical Report No. 212, Air Weather Service (MAC), U.S. Air Force, Washington, D.C., June 1969, pp. 4E1-4E11.

Bittner, Fred E., "Guide for Interpretation of Satellite Photography and Nephanalyses," Project FAMOS Research Report No. 4-67, Contract No. N62306-67-C-0284, Walter A. Bohan Co., Park Ridge, Ill., Aug. 1967, 170 pp.
Dunn, Gordon E., and Staff, "The Hurricane Season of 1963," Monthly Weather Review, Vol. 92, No. 3, Mar. 1964, pp. 128-138.

Erickson, Carl O., "Some Aspects of the Development of Hurricane Dorothy," Monthly Weather Review, Vol. 95, No. 3, Mar. 1967, pp. 121-130.

Fritz, Sigmund, Hubert, Lester F., and Timchalk, A., "Some Inferences From Satellite Pictures of Tropical Disturbances," Monthly Weather Review, Vol. 94, No. 4, Apr. 1966, pp. 231-236. Jordan, Charles L., "A Mean Atmosphere for the West Indies," National Hurricane Research Project Report No. 6, U.S. Weather Bureau, West Palm Beach, Fla., May 1957a, 17 pp.

Jordan, Charles L., "Mean Soundings for the Hurricane Eye," National Hurricane Research Project Report No. 13, U.S. Weather Bureau, West Palm Beach, Fla., Sept. $1957 b, 10$ pp.

Ramage, Colin S., "The Subtropical Cyclone," Scientific Report No. 1, Contract No. AF19(604)-6156, Meteorology Division, Institute of Geophysics, University of Hawaii, Honolulu, Apr. 1961, $26 \mathrm{pp}$.

Riehl, Herbert, Tropical Meleorology, McGraw-Hill Book Co., Ine., New York, N. Y., 1954, $392 \mathrm{pp}$.

Simpson, Robert H., "Evolution of the Kona Storm, A Subtropical Cyclone," Journal of Meteorology, Vol. 9, No. 1, Feb. 1952, pp. 24-35.

Simpson, Robert H., and Pelissier, Joseph E., "Atlantic Hurricane Season of 1970," Monthly Weather Review, Vol. 99, No. 4, Apr. 1971, pp. 269-277.

U.S. Department of Commerce, NOAA, "Rough Log, North Atlantic Weather, August-September 1970," Mariners Weather Log, Vol. 14, No. 6, Environmental Data Service, Silver Spring, Md., Nov. 1970, pp. 356-361.

[Received February 16, 1971; revised June 1, 1971] 